\title{
SEROPREVALENCE OF H9N2 SUBTYPE AVIAN INFLUENZA IN CHICKEN FARMS IN SAUDI ARABIA
}

\author{
Mahmoud M. Ismail ${ }^{*}$ and Mohamed. A. El Shorbagy ${ }^{* *}$ \\ *Department of Poultry and Fish, College of Veterinary Medicine, Kafrelsheikh University \\ ${ }^{* *}$ Department of Poultry Diseases, College of Veterinary Medicine, Banha University
}

\begin{abstract}
A total number of 3511 serum samples were collected from chicken farms in Saudi Arabia during summer of 2004 and was tested for the presence of antibodies against type A specific antigen of avian influenza virus using commercial enzyme linked immunosorbent assay (ELISA) kits. Total positive samples represented $45.81 \%$. Broiler positive samples represented $12.73 \%$. While in layers, positive samples were $30.19 \%$. Tissue samples were also taken from 5 chicken farms suffering from high mortality and respiratory signs and the H9N2 and Newcastle disease viruses were isolated and identified from these samples. These results indicate that the mild pathogenic avian influenza subtype H9N2 virus is widespread in poultry flocks in Saudi Arabia and is circulating undetected in most cases. Infection with H9N2 may pass unnoticed unless exacerbated by other co-infections like Mycoplasma gallisepticum or infectious bronchitis virus. Presence of H9N2 virus requires continuous monitoring and surveillance for possible occurrence of mutations and the risk of avian-to-human transmission.
\end{abstract}




\section{INTRODUCTION}

Influenza viruses are segmented negative-sense, single stranded RNA viruses of the family Orthomyxoviridae, and are divided into type $\mathrm{A}, \mathrm{B}$, and $\mathrm{C}$ based on the antigenic structure of their nucleocapsid and matrix protein. Only type A viruses cause natural infection in birds. Type A influenza viruses are further subdivided into subtypes based on the antigenic relatedness of the surface glycoprotein hemagglutinin $(\mathrm{H})$ and neuraminidase $(\mathrm{N})$. Till now, 16 subtypes of $\mathrm{H}$ and 9 subtypes of $\mathrm{N}$ have been identified (Bank et al., 2000; Swayne and Halvorson 2003 and Fouchier et al., 2005).

Highly pathogenic avian influenza (HPAI) viruses cause high mortality that may approach $100 \%$. Other mild pathogenic (MPAI) viruses cause inapparent infection unless exacerbated by other complicating pathogens or unfavorable environmental conditions.

An avian influenza outbreak in broiler, layer and breeder farms was attributed to the mild pathogenic H9N2 subtype avian influenza in Iran during 1998-01. Mortality between 20 and 60\% was observed. Mixed infections with other respiratory pathogens particularly infectious bronchitis virus and Mycoplasma gallisepticum were thought to be responsible for such high mortality. Clinical signs included swelling of the periorbital tissues and sinuses, respiratory discharge and respiratory distress (Marandi and Fard 2002; Nili and Asasi 2002 and Nili and Asasi 2003). Similar outbreak of H9N2 in chickens occurred in northern Pakistan in 1998 and infections resulted in sudden drop in egg production, mortality of 2 to $3 \%$ per day and respiratory lesions. Vaccination and biosecurity was used to control these infections. (Naeem and Hussain 1995 and Naeem et al., 2003). In an experimental study 
Kishida et al., (2004) found that when H9N2 virus was intranasally inoculated in Specific pathogen free (SPF) chickens, the virus was recovered from meat and bone marrow of birds showing no overt signs. On the other hand when chickens were co-infected with Staphylococcus aureus or Haemophilus paragallinarum, severe clinical signs developed and H9N2 virus was recovered more efficiently from chickens.

The occasional isolation of H9N2 avian influenza virus beside demand of poultry producers for the introduction of H9N2 virus vaccine raised the question whether MPAI infections were circulating in poultry flocks and going unrecognized. This epidemiologic investigation was therefore conducted to determine whether undetected MPAI infections were occurring in Saudi Arabia.

\section{MATERIALS \& METHODS}

\section{Serum Samples:}

A total number of 3511 blood samples were collected from chicken flocks located in different geographical regions distributed throughout the country's different districts and provinces. Samples were collected during summer of 2004. Until this time, H9N2 vaccine was not authorized for use in the country. Hence all flocks were not vaccinated against H9N2 subtype avian influenza virus. Samples included broiler and layer flocks. Serum samples were tested for the presence of serum antibodies against specific antigen for type A influenza viruses. For this purpose, commercially available enzyme-linked immunosorbent assay (ELISA) kits (BioCheck B. V. AN Gouda, Holland) were used according to manufacturer's directions. Serum samples were diluted 1:500 before use. 


\section{Virus Isolation:}

Trachea, lungs and spleens were collected from 5 broiler flocks suffering from severe respiratory signs and high mortality approaching $80 \%$. Tissue samples were homogenized and samples from same flock pooled together. Tissue homogenates were diluted 1:10 in Phosphate buffered saline (PBS). Then clarified by low speed centrifugation at 3000 rpm for 30 minutes. Supernatants were filtered through $0.8 \mu \mathrm{m}$ syringe filters and then $0.45 \mu \mathrm{m}$ filters (corning Glassware, New York), filtrate was inoculated into 10 days old chicken embryos via the allantoic cavity route. Allantoic fluid was harvested 72 hours post inoculation. Negative control embryos were inoculated with PBS ( $\mathrm{pH} 7.4)$. Allantoic fluid was tested for hemagglutination activity (HA). Positive HA samples were sent to Central veterinary Laboratories, Weybridge, UK. for virus identification and subtyping. Virus typing was performed using conventional procedures; hemagglutination inhibition (HI) and neuraminidase inhibition (NI) tests (Beard et al., 1989). Convalescent sera were also collected from these flocks to test for presence of type A influenza specific antibodies using ELISA as described previously.

\section{RESULTS}

From ELISA results, it is obvious that type A specific antibodies were detected from sera collected from chicken farms. Total positive samples were $45.81 \%$. The greatest detection rate was observed among layer flocks $30.19 \%$. Broilers positive samples represented $12.37 \%$. The greatest percentage $(93.3 \%)$ was recorded in Alzolfi province while the lowest rate was in Tarief province (4.7\%) (Table.1). H9N2 and Newcastle disease viruses were also isolated from 5 broiler chicken farms suffering from high mortality and respiratory troubles (Table 2). 
Mahmoud M. Ismail., et. al.

Table (2): Results of virus isolation from tissues and ELISA titers of convalescent sera from the same flocks that suffered from high mortality and respiratory signs.

\begin{tabular}{|c|c|c|c|c|c|c|c|}
\hline $\begin{array}{l}\text { Age \& Type of } \\
\text { production }\end{array}$ & $\begin{array}{c}\text { No. of } \\
\text { serum } \\
\text { samples }\end{array}$ & $\begin{array}{l}\text { Positive } \\
\text { samples }\end{array}$ & $\begin{array}{c}\text { Range of } \\
\text { antibody } \\
\text { titers }\end{array}$ & $\overline{\text { G.M.T }}$ & $\overline{C \text { C.V (\%) }}$ & $\begin{array}{c}\text { H9N2 } \\
\text { isolation }\end{array}$ & $\begin{array}{c}\text { NDV } \\
\text { isolation }\end{array}$ \\
\hline 35 days old broilers & $\overline{20}$ & $\overline{18}$ & (681-3762 & 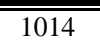 & 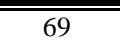 & $\overline{+}+$ & $\overline{+}+$ \\
\hline 30 days old broilers & 7 & 6 & $860-2751$ & 1367 & 47 & + & + \\
\hline 25 days old broilers & 26 & 25 & $1198-7343$ & 3324 & 43 & + & + \\
\hline 29 days old broiler & 15 & 14 & $940-4281$ & 1906 & 60 & + & + \\
\hline 28 days old broilers & 27 & 11 & $844-5819$ & 522 & 117 & + & + \\
\hline
\end{tabular}

$\mathrm{NDV}=$ Newcastle disease virus. $\mathrm{C} . \mathrm{V}=$ Coefficient of variation

\section{DISCUSSION}

The present study using ELISA revealed that antibodies against type A specific influenza virus is present in high proportion in chicken farms. The higher prevalence in layers (30.19\%) can be explained on the basis that layers are kept for long periods and have more chance to be exposed to infection with H9N2 virus at some point of time in their relatively longer lifetime than broilers with subsequent formation of detectable antibodies. Infection may produce mild respiratory signs, drop in egg production or may pass unnoticed depending on flock general condition and other concurrent infections. There are growing concerns about role of H9N2 AIV in public health. H9N2 have been isolated from two children with fever and cold like symptoms in Hong Kong in 1999. Another documented case of avian to human interspecies transmission was recorded in a child in Hong Kong in 2003. These viruses were found to be genetically closely related to virus isolated from poultry in Hong Kong which provide evidence that these viruses were of avian origin (Guan et al., 1999; Butt et al., 2005). H9N2 contain receptor binding profile that favors infection of human and some strains have gene segments previously associated with human disease (Peiris et al., 1999; Lin et al., 2000). H9N2 virus was also found to share six internal gene Kafrelsheikh Vet. Med. J. Vol. 4 No. 2 (2006) 
segments with the HPAI H5N1 virus. There is possible role for H9N2 virus as donor of virulence factors to human influenza viruses. It was found that H9N2 was the donor of internal genes to H5N1 subtype that caused disease in human (Cameron et al., 2000) Thus, presence of more than one subtype in the poultry raises the concern of possible reassortment and emergence of different subtypes. Until recently HPAI viruses were rarely isolated from wild birds, but for MPAI viruses, extremely high rate have been recorded in surveillance studies, with overall figures of about $11 \%$ in ducks and geese and around $2 \%$ for all other species. The isolation of H9N2 from wild birds and waterfowl (Okazaki et al., 2000) suggests possible role for wild birds in perpetuating and transmitting infection with this virus to commercial poultry flocks and necessitates continuous monitoring of virus in wild birds.

As H9N2 viruses are not highly pathogenic for poultry it makes them more likely to be of pandemic relevance. In fact, viruses which are not highly pathogenic for poultry have a greater opportunity to become wide spread since they do not raise concern and permit their hosts to survive unhindered and they are free to continue to replicate and reassort and more likely to have the opportunity to find the best gene constellation which permits infection to humans (Scholtissek et al., 1985; Li et al., 2003).

The MPAI H9N2 virus apparently has spread in Asian countries. However these outbreaks have always been overshadowed by H5N1 HPAI virus initially isolated from China in 1997 and has now spread in poultry throughout Asia, Europe and Africa resulting in the death or culling of hundreds of millions of poultry and posing a significant zoonosis threat. When chemically immunosuppressed chickens were challenged with H9N2 virus intratracheally, 50\% mortality was recorded 
within one week (Bano et al., 2003). Similar situations occurs in field conditions when birds are immunosuppressed due to infectious bursal disease, chicken infectious anemia virus, Marek's disease, Adenoviruses, and mycotoxicoses. Possible scenario in the field is that immunocompromised birds get infected with H9N2 virus and then followed by any of complicating pathogens. Due to recovery of H9N2 virus from meat and bone marrow of experimentally infected chickens (Kishida et al., 2004). Imported frozen chickens from countries where H9N2 is endemic must be looked at as potential source of introducing the MPAI virus H9N2. Occasional reports of respiratory problems must now include H9N2 in differential diagnosis

In Egypt, and due to similar circumstances that exist in poultry industry and the importation of frozen poultry from several countries, the presence of H9N2 must be also taken in consideration. Further studies must be pursued to confirm or to exclude the occurrence of H9N2 virus in poultry in Egypt.

\section{REFERENCES}

- Bank, J.; Speidel, E. C.; Harris, P. A.; and Alexander, D. J. (2000): Phylogenetic analysis of influenza A viruses of $\mathrm{H} 9$ hemagglutinin subtypes. Avian Pathology 29: 353-360.2000.

- Bano, S.; Naeem, K. and Malik, S. A. (2003): Evaluation of pathogenic potential of avian influenza virus serotype H9N2 in chickens. Avian Diseases 47: 817-822.

- Beard, C. W.; Purchase, H. G.; Arp, L. H.; Domermuth, C. H. and Pearson, J. E. (1989): Serological procedures In: Laboratory manual for the isolation and identification of Avian Pathogens. Purchase H. G Arp, L. H.; Domermuth, C. H. and 
Pearson, J. E. eds., Pp 192-200. Kennet Square PA: American Association of Avian Pathologists.

- Butt, K. M.; Smith, G. J.; Chen, H.; Zhang, L. J; Leung, Y. H.; XU, K. M. Lim, W.; Webster, R. G.; Yuen, K. Y.; Peiris, J. S. and Guan, $Y$. (2005): Human infection with an avian influenza H9N2 in Hong Kong in 2003. J. Clin. Microbiol. 43: 5760-5767.

- Cameron, K. R.; Gregory V.; Banks, J.; Brown, I. H.; Alexander, D. J.; Hay, A. J.; and Lin, Y. P. (2000): H9N2 subtype influenza viruses in Pakistan are closely related to the H9N2 viruses responsible for human infection in Hong Kong. Virology. 278: 36-41.

- Fouchier, R. A.; Munster, F. V.; Wallensten, A.; Bestebroer, T. M; Herfest, S.; Smith, D.; Rimmelzwaan, G. F.; Olsen, B. and Osterhaus, A. D. (2005): Characterization of a novel influenza A virus Hemagglutinin subtype (H16) obtained from black-headed Gulls. J. of Virology. 79: 2814-2822.

- Guan Y.; Shortridge, K. F.; Krauss, S. and Webster R. G. (1999): Molecular characterization of influenza viruses H9N2; were they the donors of the internal genes of $\mathrm{H} 5 \mathrm{~N} 1$ viruses responsible for human infection in Hong Kong. Proceedings of National Academy of Science. USA. 96: 9363-9367.

- Kishida, N.; Sakoda, Y.; Eto, M.; Sunaga, Y.; and Kida H. (2004): Co-infection of Staphylococcus aureus or haemophilus paragallinarum exacerbates $\mathrm{H} 9 \mathrm{~N} 2$ influenza $\mathrm{A}$ virus infection in chickens. Arch. Virol. 149: 2095-2104.

- Li, K. S., Xu. K. M., Peiris, J. S. M., Poon, L. L. M., Yu, K. Z., Yuen, K. Y., Shortridge, K. F., Webster, R. G., and Guan, Y. (2003): Characterization of H9 subtype influenza viruses from the ducks of southern China: a candidate for the next influenza pandemic in humans? Journal of Virology 77: 6988-6994. 
- Lin, Y. P.; Shaw, M.; Gregory V.; Cameron K.; Lim W.; Klimov, A.; Subbaro K.; Guan, Y.; Krauss, S.; Shortridge, K.; Webster, R.; Cox, N.; Hay, A. (2000): Avian-to-human transmission of H9N2 subtype influenza A viruses: Relatioship between H9N2 and H5N1 human isolates. Proc. Natl. Acad. Sci. USA 97: 9654-9658.

- Marandi, M. V. and Fard, M. H. (2002): Isolation of H9N2 subtype of avian influenza viruses during an outbreak in chickens in Iran. Iran. biomedical Journal. 6: 13-17.

- Naeem, K. and Hussain, M. (1995): An outbreak of avian influenza in Pakistan. Vet. Rec.137, 439.

- Naeem, K.; Naurin, M.; Rashid, S. and Bano, S. (2003): Seropreval-ence of avian influenza virus and its relationship with increased mortality and decreased egg production. Avian Pathology: 32 (3) 285-289.

- Nili, H. and asasi, K. (2002): Natural cases and an experimental study of H9N2 avian influenza in commercial broiler chickens of Iran. Avian Pathol. 31: 247-252.

- Nili, H. and Asasi, K. (2003): Avian influenza (H9N2) outbreak in Iran. Avian Diseases 47: 828-831.

- Okazaki, K A Takada T; Ito M Imai, H M Hatta H.; Ozaki, T.; Tanizaki, T.; Nagano, A; Ninomiya, V. A.; Demenev, M. M.; Tyaptirganov, T. D.; Karatayeva, S. S.; Yamnikova, D. K.; Lvov, and Kida H. (2000): Precursor genes of future pandemic influenza viruses are perpetuated in ducks nesting in Siberia. Arch. Virol. 145: 885-893.

- Peiris, M., Yuen, K. Y., Leung, C. W., Chan, K. H., Ip, P. L. S., Lai, R. W. M., Orr, W. K., Shortridge, K. F., (1999): Human infection with influenza H9N2. Lancet 345: 916-917. 
- Scholtissek, C., Burger, H., Kistner, O., and Shortridge, K. F. (1985): The nucleoprotein as a possible major factor in determining host specificity of influenza H3N2 viruses. Virology 147: 287-294.

- Swayne, D. E. and Halvorson, D. A. (2003): Influenza In: Diseases of Poultry. 11 ${ }^{\text {th }}$ eds., Saif, Y. M.; Barnes H. J. ; Glisson, J. R.; Fadly A. M., McDougald, L. R. and Swayne, D. E. eds. Iowa State University Press, Ames, Iowa. Pp. 135-160.

مدى تواجد عترة أنفلونز ا الطيور المتوسطة الضر اوة (H9N2) بمز ارع الدجاج بالمملكة العربية السعودية المونة

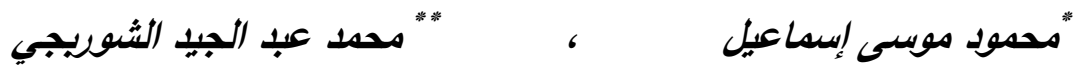

قسم الدواجن والأسماك - كلية الطب البيطري / "جامعة كفر الثيخ ، "جامعة بنها

تم إجراء هذه الدراسـة لمعرفة مـا إذا كانت العترة متوسطة الضراوة (H9N2) متواجدة بمزارع الدواجن بالمملكة العربيـة السعودية. تم تجميع عدد 3511 عينـة دم من مزارع تسمين ومزارع دجاج بياض خلال صيف عام 2004 من محافظات ومناطق متفرقة بالمملكة. تم بعد ذلك إجراء اختبار الإليزا على هذه العينات لقياس نواجد الأجسام المناعية لفيروس (H9N2) المنوسط الضراوة. وجاءت النتائج إيجابية بنسبة \% 45.81 من المجموع الكلي للعينات. وهذه النتائج تؤكد تواجد العترة (H9N2) ودورانها فى قطعان الدواجن والذي غالبا ما يكون غيرَ ملموس نظرا لعدم مقدرة هذه العترة على إحداث مرض بالطيور إذا مـا كانت الحالة الصحية للطيور جيدةً ولم تتواجد مسببات مرضية أخرى متزامنة 
معها نتساعد على ظهور المرض. كما أن خطورة هذه العترة تتمثل فى إمكانيـة حدوث طفرات لها وتحولها إلى عترة عالية الضراوة وقد نم تسجيل بعض الحالات في الإنسان ثبت فيها انتقال هذه العترة من الطيور للإنسان فى هونج كونج وإحداثها حالة مرضيه خفيفة نتشبه أعراض البرد العادي. ومن هذه النتائج يتضح ضرورة التحصين باللقاح الميت لتلك العترة للحد من دورانها. 